\title{
Implementasi dan Analisis Quality of Service (QoS) pada OpenMeetings dengan Virtual Private Network (VPN)
}

\author{
Ibel Dwi Amizal, Lindawati ${ }^{2}$, dan Sopian Soim ${ }^{3}$ \\ ${ }^{1}$ Politeknik Negeri Sriwijaya, Teknik Elektro, ${ }^{2}$ Politeknik Negeri Sriwijaya, Teknik Elektro \\ ${ }^{3}$ Politeknik Negeri Sriwijaya, Teknik Elektro \\ ibel.amizad1001@gmail.com,lindawati@polsri.ac.id,sopiansoim@gmail.com
}

Coprespondent Author : Ibel Dwi Amiza

\begin{abstract}
Video Conference is a communication service that can be used to bring together two users (client) or more. Video conferencing can be used for a variety of activities that require communication in real-time without having to come face to face directly. One open-source that can be utilized as a means of communicating is OpenMeetings. OpenMeetings uses IP and in the same network as a means of conducting video conferencing between clients. But if a client is not in the same network, it can utilize the Virtual Private Network (VPN) technology. The VPN can be remote by using a MikroTik router. The Video conferencing service requires fairly high and stable connectivity. Quality of Service $(Q 0 S)$ can be used whether the network is eligible for video conferencing. The QoS parameters used are throughput and packet loss. The QoS test can be done using Wireshark.
\end{abstract}

Keyword - Video conference, OpenMeetings, VPN, QoS, Wireshark.

Abstrak - Video conference adalah suatu layanan komunikasi yang dapat digunakan untuk mempertemukan dua pengguna (client) ataupun lebih. Video conference dapat dimanfaatkan untuk berbagai kegiatan yang membutuhkan komunikasi secara real time tanpa harus bertatap muka secara langsung. Salah satu open source yang dapat dimanfaatkan sebagai sarana berkomunikasi adalah OpenMeetings. OpenMeetings menggunakan IP dan dalam jaringan yang sama sebagai sarana untuk melakukan video conference antar client. Namun jika suatu client sedang tidak berada dalam suatu jaringan yang sama, maka dapat memanfaatkan teknologi Virtual Private Network (VPN). VPN dapat diremote dengan menggunakan MikroTik router. Layanan video conference membutuhkan suatu konektifitas yang cukup tinggi dan stabil. Quality of Service (QoS) dapat digunakan apakah jaringan tersebut layak untuk melakukan video conference atau tidak. Parameter QoS yang digunakan berupa throughput, packet loss. Pengujian QoS tersebut dapat dilakukan menggunakan wireshark

Kata kunci - Video conference, OpenMeetings, VPN, QoS, Wireshark.

\section{PENDAHULUAN}

Teknologi yang semakin berkembang dengan pesat menjadikan informasi dan komunikasi sebagai salah satu kebutuhan yang sangat diperlukan. Hal tersebut dapat dilihat dari pemakaian internet sebagai jaringan global. Perkembangan teknologi berbanding lurus dengan perkembangan berkomunikasi. Saat ini komunikasi tidak hanya dapat dilakukan secara bertatap muka atau secara langsung, melaikan dapat juga melalui media elektronik seperti, chatting, panggilan suara maupun video call dan kini telah berkembang menjadi video conference.

Video conference merupakan suatu layanan multimedia yang melakukan komunikasi berupa data, suara dan gambar secara dua arah atau duplex serta memiliki sifat real time. Video conference dilakukan guna berkomunikasi jarak jauh namun seolah komunikasi tersebut dilakukan seperti tatap muka secara langsung [1]. Video conference dapat dilakukan dengan menggunakan komputer atau laptop yang memiliki webcam atau bahkan saat ini video conference juga sudah dapat dilakukan dengan media smartphone dimanapun dan kapanpun [2].

Salah satu aplikasi yang dapat menjalankan video conference yaitu OpenMeetings. OpenMeetings merupakan suatu aplikasi open source yang menyediakan video conference, pesan instan, papan tulis, melakukan pengeditan dokumen kolaboratif dan groupware tools lainnya. OpenMeetings menyediakan berbagai rooms baik public rooms yang dapat diakses oleh client yang terhubung dengan suatu jaringan local yang sama dengan menggunakan Internet Protocol (IP). Selain itu, juga terdapat private rooms yang dapat dilakukan dengan undangan secara pribadi ke client yang kemudian akan mendapatkan suatu link untuk bergabung.

Dengan kemampuan bergabung menggunakan jaringan yang sama tersebut maka dapat dikatakan video conference memiliki kemampuan yang baik dalam hal keamanan. Hal tersebut karena client yang tidak tergabung dalam satu jaringan yang sama tidak akan bisa mengakses layanan. Namun jika ada client yang ingin bergabung tetapi sedang tidak berada dalam jaringan lokal server tersebut, maka dibangunlah Virtual Private Network (VPN). VPN merupakan suatu teknologi dimana penggunanya dapat bergabung dengan jaringan local menggunakan jaringan public [3].

VPN dapat dibangun dengan beberapa cara, salah satunya dengan menggunakan open source FreeDDNS. FreeDDNS adalah website yang menyediakan layanan VPN Remote, Cloud Hosting, HTTP Reverse Proxy serta DDNS untuk router atau device [4]. Setelah list VPN dibangun, selanjutnya VPN diremote menggunakan router MikroTik. 
Untuk meneruskan VPN ke OpenMeetings maka dilakukan konfigurasi VPN dengan menggunakan Network Address Translation (NAT) dengan MikroTik pada WinBox. NAT merupakan metode yang digunakan untuk menghubungkan beberapa komputer ke jaringan internet dengan satu alamat IP [5].

\section{DASAR TEORI}

\section{A. Video Conference}

Video conference merupakan suatu sistem yang dirancang guna memudahkan dua orang atau lebih berkomunikasi dalam jarak yang berbeda namun dengan waktu yang bersamaan. Video conference menggunakan telekomunikasi yang meliputi pelayanan data, voice, multimedia dan berupa video dan audio serta internet [6].

Video conference mengirimkan data secara realtime maka dari itu layanan video conference membutuhkan bandwidth, konektifitas serta kestabilan yang cukup tinggi. Video conference melakukan download dan uplink pada data yang dikirim dan diterima. Video conference menggunakan data pada internet lebih banyak karena layanan video conference melakukan koneksi dua arah [7]. Video conference dapat dimanfaatkan untuk berbagai macam kegiatan yang membutuhkan komunikasi real-time tanpa batasan waktu dan tempat. Beberapa contoh kegiatan yang dapat memanfaatkan video conference adalah rapat online, sekolah atau kuliah online, pelatihan online dan lain- lain.

\section{B. Virtual Private Network}

Virtual Private Network (VPN) merupakan teknologi dalam komunikasi yang dapat menghubungkan jaringan public ke jaringan local. Dengan begitu, suatu jaringan public tersebut bisa mendapatkan hal dan pengaturan yang sama dengan suatu jaringan local. VPN menyediakan beberapa fungsi untuk penggunanya antara lain confidentially (kerahasiaan), data integrity (kebutuhan data), origin authentation (autentikasi sumber), non-repudiation dan kendali akses [3].

\section{Router}

Router merupakan sebuah perangkat keras yang digunakan untuk melewatkan IP dari suatu jaringan ke jaringan lainnya. Router berkemampuan melewatkan IP dari suatu jaringan ke jaringan lainnya yang mungkin memiliki lebih dari satu jalur [8].

\section{MikroTik Router}

MikroTik router merupakan suatu perangkat keras dalam jaringan komputer yang menggunakan sistem operasi berupa software MikroTik RouterOS dan diperuntukkan bagi network router. MikroTik Router OS adalah suatu sitem operasi yang dibangun untuk network router. MikroTik Router OS didesain untuk memberikan kemudahan bagi pengguna [8]. MikroTik router memiliki beberapa fungsi yaitu bandwidth management, stateful firewall, hotspot for plug and paly access, remote WinBox GUI admin serta routing. Proses administrasi MikroTik router menggunakan Windows Application (WinBox) [5].

\section{E. Quality of Service}

Qulaity of Service (QoS) adalah salah satu metode yang digunakan sebagai pengukuran kinerja suatu jaringan. QoS digunakan untuk mengetahui karakteristik dan sifat dari suatu layanan [9]. Telecomunications and Internet Protocol Harmonization Over Networks (TIPHON) membagi QoS dalam beberapa parameter diantaranya throughput, dan packet loss

\section{1) Throughput}

Throughput adalah kecepatan (rate) transfer data data yang diukur dalam satuan bps (bit per second). Throughput merupakan jumlah total kedatangan paket yang sukses dan diamati pada tujuan dalam interval waktu tertentu dibagi dengan durasi interval waktu tersebut [9].

TABEL I

KATEGORI NILAI THROUGHPUT

\begin{tabular}{lcc}
\multicolumn{1}{c}{ Kategori } & Throughput (bps) & Indeks \\
\hline Sangat Bagus & 100 & 4 \\
Bagus & 75 & 3 \\
Sedang & 50 & 2 \\
Jelek & $<25$ & 1 \\
\hline
\end{tabular}

Sumber: TIPHON

Persamaan throughput:

$$
\text { Throughput }=\frac{\text { Packet data yang diterima }}{\text { Lama pengamatan }}
$$

\section{2) Packet Loss}

Packet Loss menggambarkan suatu kondisi jumlah total packet yang hilang dapat terjadi karena collision dan congestion pada suatu jaringan [9].

TABEL II

KATEGORI NILAI PACKET LOSS

\begin{tabular}{lcc}
\multicolumn{1}{r}{ Kategori } & Packet Loss $(\%)$ & Indeks \\
\hline Sangat Bagus & 0 & 4 \\
Bagus & 3 & 3 \\
Sedang & 15 & 2 \\
Jelek & 25 & 1 \\
\hline
\end{tabular}

Sumber: TIPHON

Persamaan packet loss:

Packet loss $=$

$\frac{\text { Packet yang dikirim -Packet yang diterima }}{\text { Packet data yang dikirim }}$ X100\% 


\section{METODOLOGI PENELITIAN}

\section{A. Kebutuhan Perangkat}

Kebutuhan perangkat terbagi menjadi dua bagian diantaranya kebutuhan perangkat keras.

\section{1) Perangkat Keras (Hardware)}

- Laptop Hewlett Packard Model 14s-cf0070TX

- Laptop user

- MikroTik Router Wireless RB952Ui-5ac2nD (hAPAC-Lite)

Spesifikasi router:

$\begin{array}{ll}\text { Product Code } & : \text { RB952Ui-5ac2nD-TC } \\ \text { RAM } & : 64 \mathrm{MB} \\ \text { LAN Ports } & : 5 \\ \text { Wireless Standarts } & : 802.11 \mathrm{a} / \mathrm{b} / \mathrm{g} / \mathrm{n} / \mathrm{ac} \\ \text { RouterOS License } & : \text { Level4 }\end{array}$

\section{2) Perangkat Lunak (Software)}

\section{- OpenMeetings}

OpenMeetings menggunakan fungsi Application Programming Interface atau API media server, yaitu software yang mengizinkan dua aplikasi terhubung satu sama lain sebagai remoting dan menggunakan Red5 atau Kurento sebagai server streaming yang berbasis Java yang mendukung streaming audio ataupun video [10].

\section{- WinBox}

WinBox merupakan software atau utility yang digunakan sebagai remote untuk sebuah server MikroTik dan kemudian memasukkannya dalam sebuah mode Graphical User Interface (GUI) melalui sepuah operating sistem windows [5].

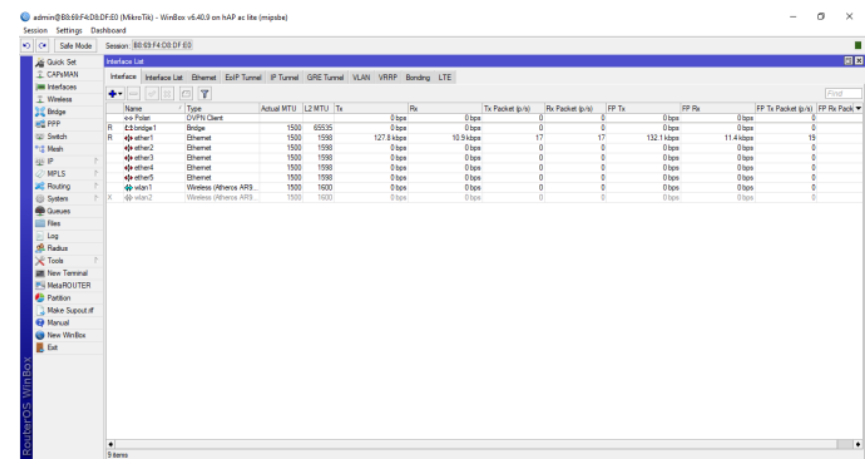

Gambar 1. Tampilan WinBox.

- Wireshark

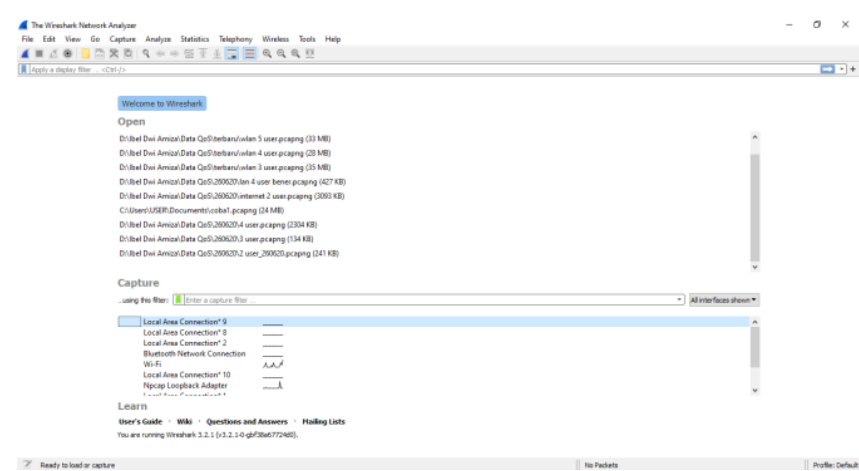

Wireshark merupakan aplikasi yang digunakan untuk melakukan perhitungan QoS.

Gambar 2. Tampilan wireshark.

\section{B. Pemodelan Jaringan}

Pemodelan jaringan dilakukan untuk mengetahui kinerja jaringan pada layanan vieo conference yang ingin dipantau. Pada penelitian ini, layanan video conference yang akan

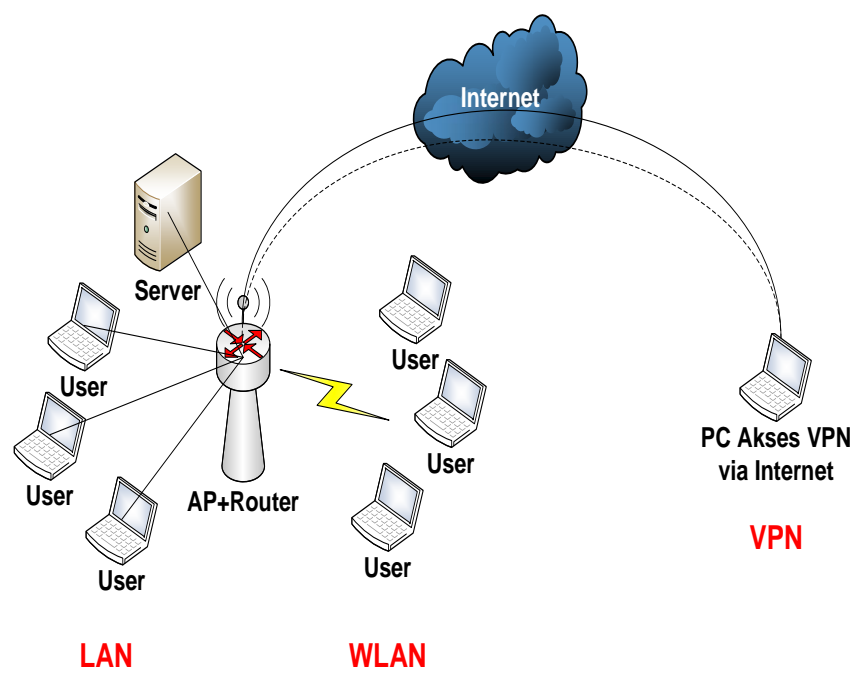

dianalisa adalah layanan dengan jaringan LAN, WLAN dan internet public dengan VPN.

Gambar 3. Topologi layanan video conference.

Gambar 3 merupakan topologi jaringan untuk layanan video conference yang telah dibangun dan akan dilakukan pengujian. Pengujian terbagi atas tiga skenario jaringan, yakni dengan jaringan LAN, WLAN dan internet public dengan VPN.

\section{Konfigurasi Jaringan}


Pada perancangan jaringan terbagi atas dua konfigurasi yakni konfigurasi video conference dan konfigurasi VPN. Berikut diagram alir untuk perancangan konfigurasi layanan video conference dan VPN.

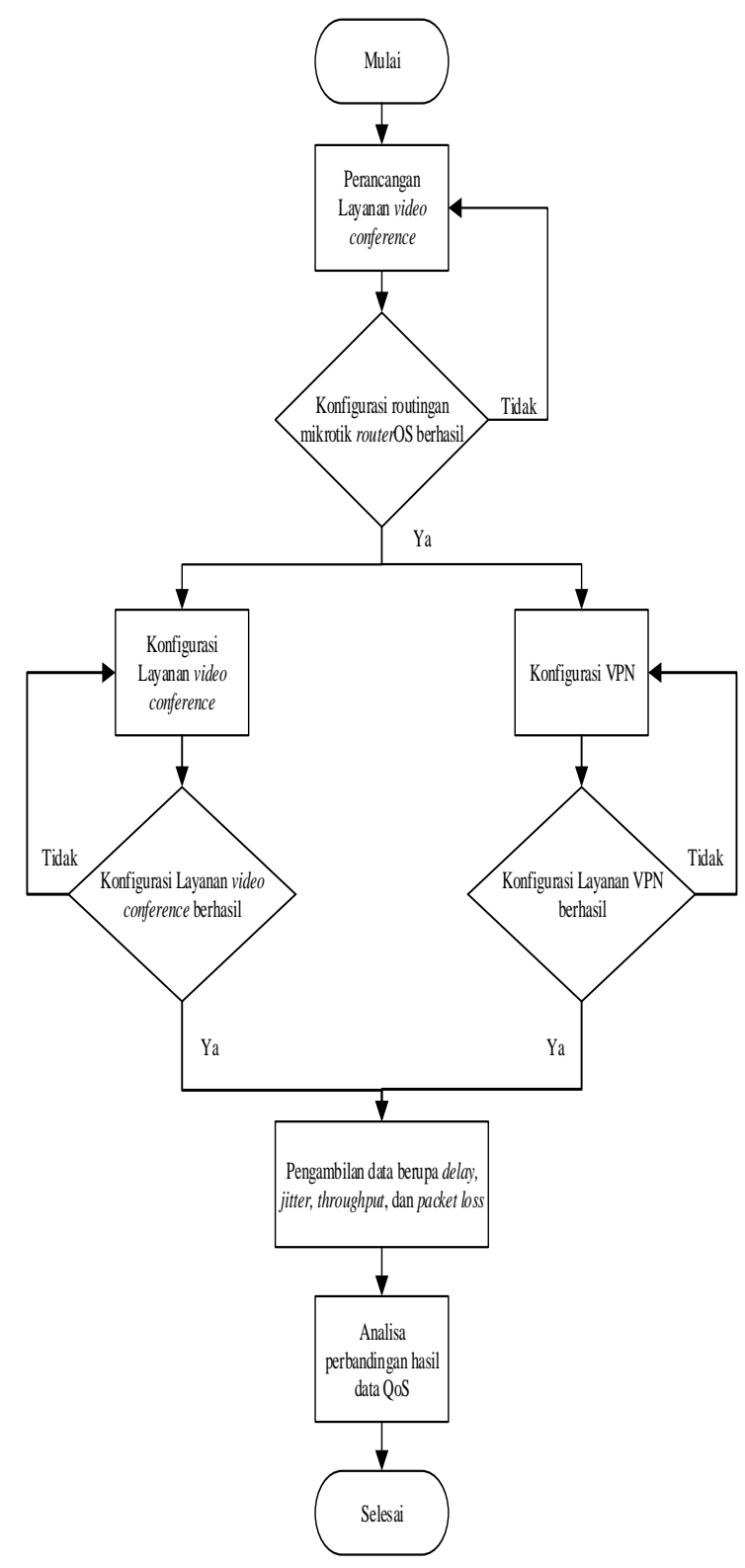

Gambar 4. Diagram alir konfigurasi video conference dan VPN.

Konfigurasi OpenMettings memerlukan beberapa software pendukung antara lain: Ghostscript and 7-Zip, Oracle Java 1.8, LibreOffice, ImageMagick dan Sox, Adobe Flash Player, Compilation of FFmpeg (Lame, Fdk-aac, X-264, FFmpeg), MariaDB data server, Apache OpenMeetings serta red5-OpenMeetings.

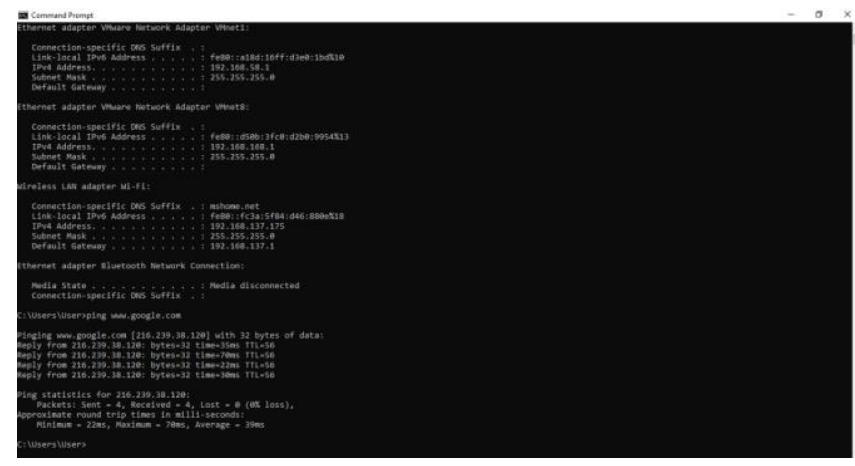

Konfigurasi video conference dimulai dengan pengecekan IP pada laptop dengan menggunakan Command Prompt seperti gambar berikut ini.

\section{Gambar 5. IP configuration}

Untuk skenario percobaan menggunakan LAN berikut adalah daftar IP yang digunakan pada MikroTik router.

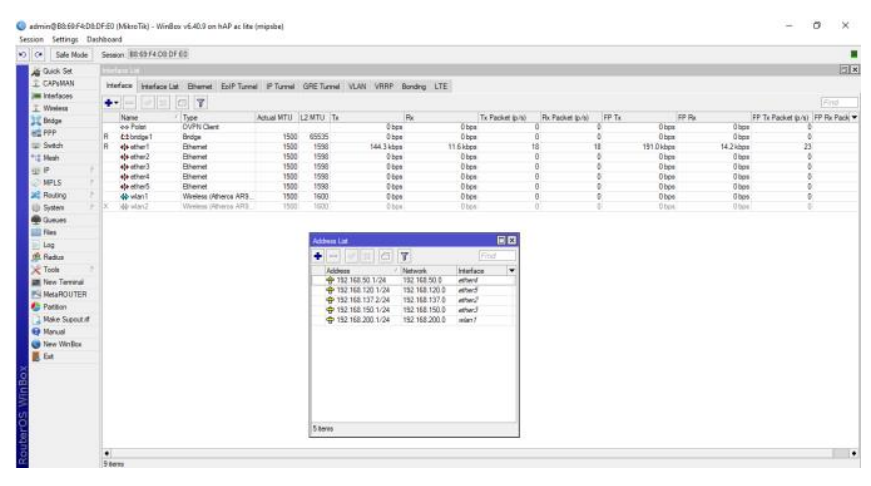

Gambar 6. Addresses List pada MikroTik.

Aplikasi batch file red5 untuk menjalankan server OpenMeetings. Tunggu beberapa saat sampai red5 menampilkan skrip dan batch files "OpenMeetings is up" seperti gambar dibawah ini.

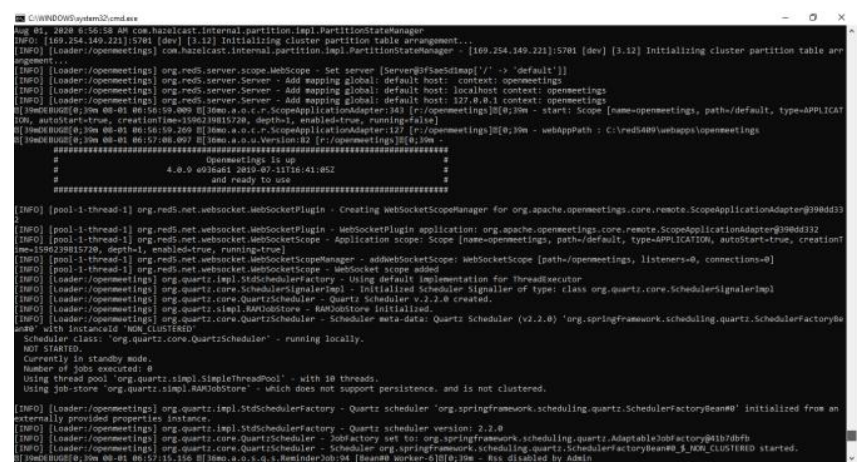

Gambar 7. Tampilan red5. 
Selanjutnya untuk melakukan konfigutasi VPN dimulai dengan membuat akun FreeDDNS pada website https://tunnel.hostddns.us.

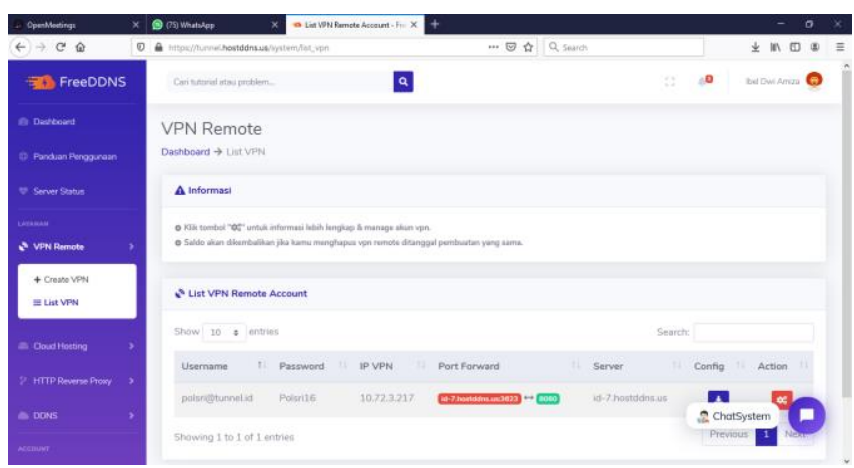

Gambar 8. List VPN remote.

Untuk meremote VPN buka router MikroTikOS pada WinBox lalu pada menu interface klik tanda tambah (+) kemudian OVPN client lalu isi option value nya sebagai berikut.

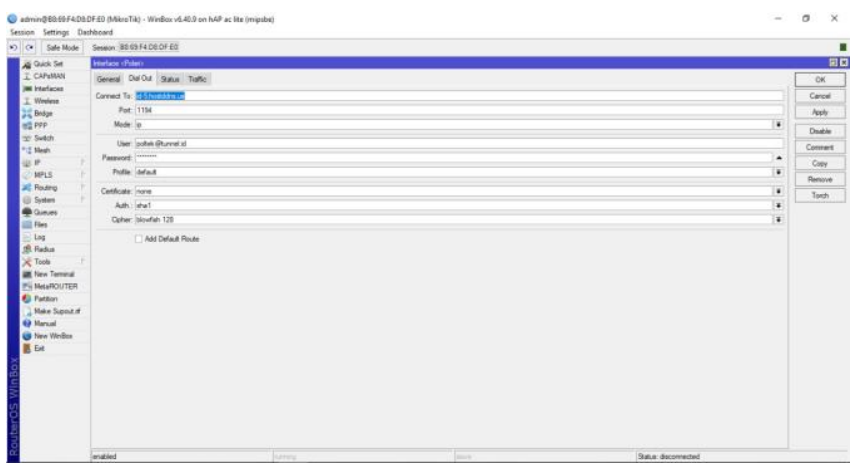

Gambar 9. Remote VPN dengan MikroTik router.

Untuk menghubungkan VPN dengan OpenMeetings dilakukan menggunakan WinBox pada menu NAT. Pada bagian General masukkan destination port 8080 (port VPN) dan bagian Action isikan To. Addresses: 192.168.137.1 (IP OpenMeetings) dan To. Port 5080 (Port OpenMeetings).

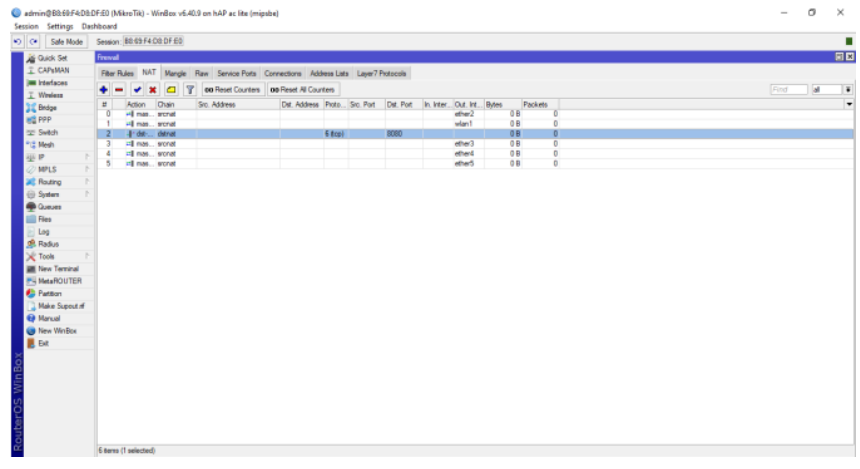

Gambar. 10 NAT pada firewall OpenMeetings.

Untuk forward ke port 5080 (port OpenMeetings) maka buka IP yang didapatkan beserta port 5080 pada halaman browser.

\section{HASIL DAN PEMBAHASAN}

A. Implementasi

1) Tampilan Login

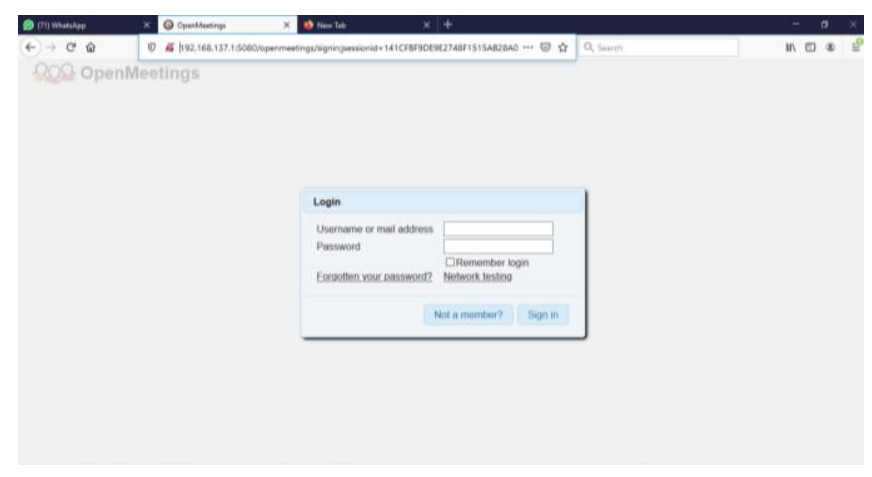

Gambar 11. Tampilan login pada OpenMeetings.

\section{2) Halaman Utama}

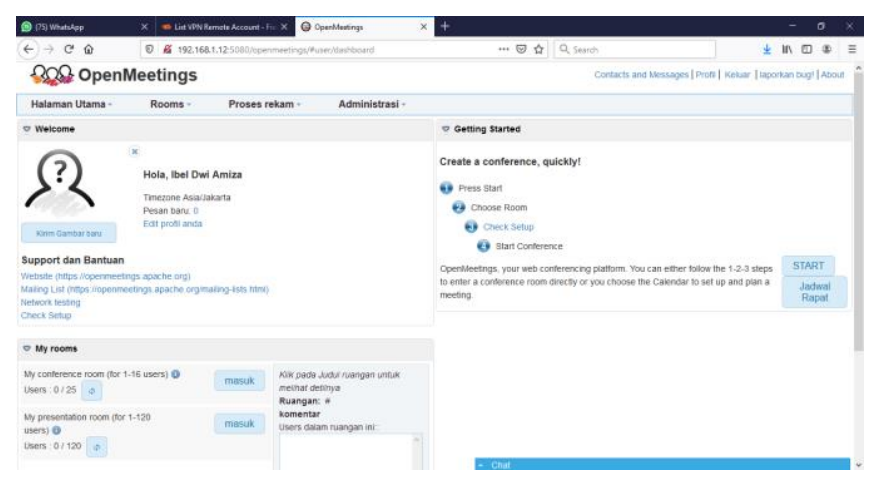

Gambar 12. Halaman Utama OpenMeeting. 


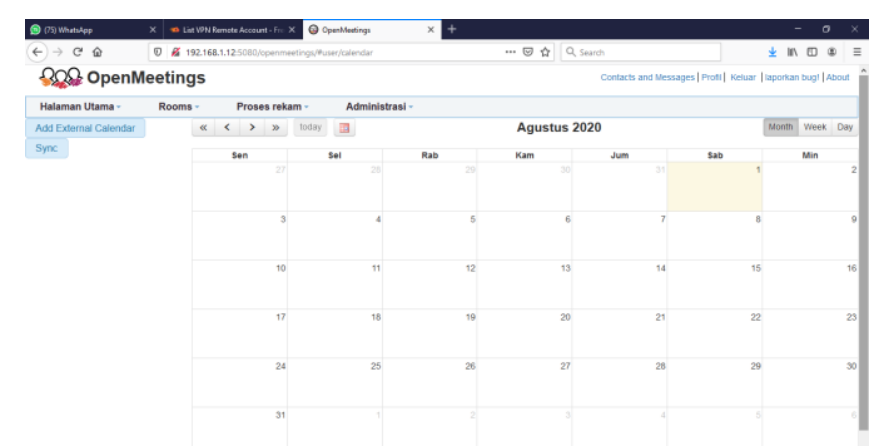

3) Jadwal Rapat

Gambar 13. Jadwal rapat pada OpenMeetings.

4) Hasil pengujian video conference dengan OpenMeetings

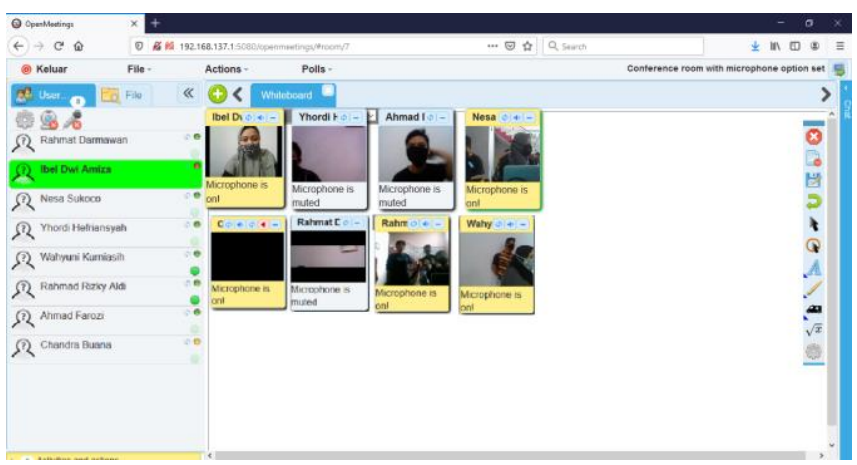

Gambar 14. Pengujian video conference dengan OpenMeetings.

\section{B. Hasil Pengujian Sistem}

Hasil pengujian sistem berisi beberapa tabel yang menjelaskan apakah setiap menu yang terdapat pada OpenMeetings telah berfungsi sesuai dengan keinginan atau tidak.

TABEL III

PENGUJIAN PADA MENU LOGIN

\begin{tabular}{|l|l|l|}
\hline \multicolumn{1}{|c|}{ Masukan } & \multicolumn{1}{c|}{$\begin{array}{c}\text { Hasil yang } \\
\text { diharapkan }\end{array}$} & \multicolumn{1}{c|}{ Status } \\
\hline $\begin{array}{l}\text { Input username } \\
\text { dan password } \\
\text { lalu menekan } \\
\text { tombol sign in }\end{array}$ & $\begin{array}{l}\text { Menu halaman utama } \\
\text { (Home Page }) \text { akan } \\
\text { ditampilkan }\end{array}$ & $\begin{array}{l}{[\sqrt{ }] \text { Sukses }} \\
{[\text { ] Gagal }}\end{array}$ \\
\hline $\begin{array}{l}\text { Menekan tombol } \\
\text { not a member? }\end{array}$ & $\begin{array}{l}\text { Menu sign up akan } \\
\text { ditampilkan }\end{array}$ & $\begin{array}{l}{[\sqrt{ }] \text { Sukses }} \\
{[\text { ] Gagal }}\end{array}$ \\
\hline Menekan tombil & Pendaftaran sebagai & {$[\sqrt{ }]$ Sukses } \\
\hline
\end{tabular}

\begin{tabular}{|l|l|l|}
$\begin{array}{l}\text { register pada } \\
\text { menu sign up }\end{array}$ & $\begin{array}{l}\text { member baru berhasil } \\
\text { disimpan }\end{array}$ & [ ] Gagal \\
\hline
\end{tabular}

TABEL IV

PENGUJIAN PADA MENU HOME PAGE

\begin{tabular}{|c|c|c|}
\hline Masukan & $\begin{array}{c}\text { Hasil yang } \\
\text { diharapkan }\end{array}$ & Status \\
\hline $\begin{array}{l}\text { Menekan menu } \\
\text { Home Page } \\
\text { Saya }\end{array}$ & $\begin{array}{l}\text { Tampilan dashboard } \\
\text { yang terdiri dari profil, } \\
\text { getting started dan } M y \\
\text { rooms akan } \\
\text { ditampilkan }\end{array}$ & $\begin{array}{l}{[\sqrt{ }] \text { Sukses }} \\
{[\text { ] Gagal }}\end{array}$ \\
\hline $\begin{array}{l}\text { Menekan menu } \\
\text { jadwal rapat }\end{array}$ & $\begin{array}{l}\text { Kalender yang berisi } \\
\text { jadwal rapat akan } \\
\text { ditampilkan }\end{array}$ & $\begin{array}{l}{[\sqrt{ }] \text { Sukses }} \\
{[\text { ] Gagal }}\end{array}$ \\
\hline $\begin{array}{l}\text { Menekan } \\
\text { tombol simpan } \\
\text { pada event } \\
\text { details }\end{array}$ & $\begin{array}{l}\text { Informasi event pada } \\
\text { kalender akan disimpan }\end{array}$ & $\begin{array}{l}{[\sqrt{ }] \text { Sukses }} \\
{[\text { ] Gagal }}\end{array}$ \\
\hline
\end{tabular}

TABEL V

PENGUJIAN PADA MENU ROOMS

\begin{tabular}{|l|l|l|}
\hline \multicolumn{1}{|c|}{ Masukan } & \multicolumn{1}{|c|}{$\begin{array}{c}\text { Hasil yang } \\
\text { diharapkan }\end{array}$} & \multicolumn{1}{c|}{ Status } \\
\hline $\begin{array}{l}\text { Menekan menu } \\
\text { public rooms }\end{array}$ & $\begin{array}{l}\text { List public rooms akan } \\
\text { ditampilkan }\end{array}$ & $\begin{array}{l}{[\sqrt{ } \text { Sukses }} \\
{[\text { ] Gagal }}\end{array}$ \\
\hline $\begin{array}{l}\text { Menekan menu } \\
\text { private rooms }\end{array}$ & $\begin{array}{l}\text { List private rooms } \\
\text { akan ditampilkan }\end{array}$ & $\begin{array}{l}{[\sqrt{ }] \text { Sukses }} \\
{[\text { ] Gagal }}\end{array}$ \\
\hline
\end{tabular}

TABEL VI

PENGUJIAN PADA MENU PROSES REKAM

\begin{tabular}{|l|l|l|}
\hline \multicolumn{1}{|c|}{ Masukan } & \multicolumn{1}{|c|}{$\begin{array}{c}\text { Hasil yang } \\
\text { diharapkan }\end{array}$} & \multicolumn{1}{c|}{ Status } \\
\hline $\begin{array}{l}\text { Menekan menu } \\
\text { proses rekam }\end{array}$ & $\begin{array}{l}\text { List rekaman yang } \\
\text { terdiri dari } \text { my } \\
\text { recordings, public } \\
\text { recordings, group } \\
\text { recordings, group files } \\
\text { recan ditampilkan }\end{array}$ & $\begin{array}{l}\text { [ ] Gagal } \\
\text { akand }\end{array}$ \\
\hline
\end{tabular}

TABEL VII 
PENGUJIAN PADA MENU ADMINISTRASI

\begin{tabular}{|l|l|l|}
\hline \multicolumn{1}{|c|}{ Masukan } & \multicolumn{1}{|c|}{$\begin{array}{c}\text { Hasil yang } \\
\text { diharapkan }\end{array}$} & \multicolumn{1}{c|}{ Status } \\
\hline $\begin{array}{l}\text { Menekan menu } \\
\text { user }\end{array}$ & $\begin{array}{l}\text { List user yang } \\
\text { terhubung akan } \\
\text { ditampilkan }\end{array}$ & $\begin{array}{l}{[\sqrt{ }] \text { Sukses }} \\
{[\text { ] Gagal }}\end{array}$ \\
\hline $\begin{array}{l}\text { Menekan menu } \\
\text { connections }\end{array}$ & $\begin{array}{l}\text { List } \text { user yang sedang } \\
\text { aktif akan ditampilkan }\end{array}$ & $\begin{array}{l}{[\sqrt{ }] \text { Sukses }} \\
{[\text { ] Gagal }}\end{array}$ \\
\hline $\begin{array}{l}\text { Menekan menu } \\
\text { group }\end{array}$ & $\begin{array}{l}\text { Group yang terhubung } \\
\text { akan ditampilkan }\end{array}$ & $\begin{array}{l}{[\sqrt{ }] \text { Sukses }} \\
{[\text { ] Gagal }}\end{array}$ \\
\hline
\end{tabular}

TABEL VIII

PENGUJIAN PADA MENU LOG OUT

\begin{tabular}{|l|l|l|}
\hline \multicolumn{1}{|c|}{ Masukan } & \multicolumn{1}{|c|}{$\begin{array}{c}\text { Hasil yang } \\
\text { diharapkan }\end{array}$} & \multicolumn{1}{c|}{ Status } \\
\hline $\begin{array}{l}\text { Menekan tab } \\
\text { Log } \text { out }\end{array}$ & $\begin{array}{l}\text { Aplikasi berhenti } \\
\text { dijalankan user keluar } \\
\text { dari aplikasi }\end{array}$ & $\begin{array}{l}{[\sqrt{ }] \text { Sukses }} \\
{[\text { ] Gagal }}\end{array}$ \\
\hline $\begin{array}{l}\text { Menekan tab } \\
\text { Log } \text { out lalu } \\
\text { menekan } \\
\text { tombol } \text { cancel }\end{array}$ & $\begin{array}{l}\text { Kembali ke tampilan } \\
\text { form sebelumnya. }\end{array}$ & $\begin{array}{l}{[\sqrt{ }] \text { Sukses }} \\
{[\text { ] Gagal }}\end{array}$ \\
\hline
\end{tabular}

\section{Quality of Service}

Pengambilan data QoS dilakukan dengan menggunakan software wireshark. Pengukuran dilakukan dengan menjalankan video conference dengan beberapa client. Parameter yang diukur berupa throughput dan packetloss. Skenario pengujian dilakukan dengan tiga tahapan yaitu menggunakan jaringan Local Area Network (LAN), Wireless Local Area Network (WLAN) dan juga internet publik menggunakan VPN.

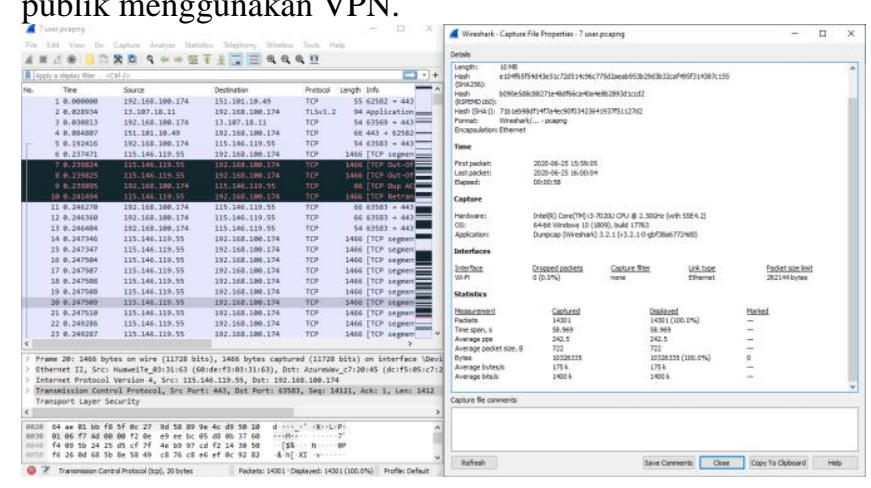

Gambar 15. Pengambilan data QoS dengan wireshark.

TABEL IX

HASIL PENGUKURAN QOS

\begin{tabular}{|c|l|l|l|}
\hline \multirow{2}{*}{$\begin{array}{c}\text { Parameter } \\
\text { Jaringan }\end{array}$} & Jumlah Client & \multicolumn{2}{|c|}{ Parameter } \\
\cline { 3 - 4 } & & $\begin{array}{c}\text { Throughput } \\
\text { (bps) }\end{array}$ & $\begin{array}{c}\text { Packet } \\
\text { Loss }\end{array}$ \\
\hline LAN & 2 client & $3.254,66$ & $0 \%$ \\
\hline
\end{tabular}

\begin{tabular}{|l|l|l|l|}
\hline & 3 client & $2.648,96$ & $0 \%$ \\
\cline { 2 - 4 } & 4 client & $5.095,45$ & $0 \%$ \\
\cline { 2 - 4 } & Rata-rata & $3.666,356$ & $0 \%$ \\
\hline \multirow{7}{*}{ WLAN } & 2 client & $27.551,18$ & $2,4 \%$ \\
\cline { 2 - 4 } & 3 client & $14.345,89$ & $1,3 \%$ \\
\cline { 2 - 4 } & 4 client & $266.159,56$ & $3,6 \%$ \\
\cline { 2 - 4 } & 5 client & $7.485,69$ & $1,2 \%$ \\
\cline { 2 - 4 } & 6 client & $5.440,192$ & $0 \%$ \\
\cline { 2 - 4 } & 7 client & $140.091,64$ & $3,8 \%$ \\
\cline { 2 - 4 } & Rata-rata & $76.845,692$ & $2,05 \%$ \\
\hline \multirow{7}{*}{ INTERNET } & 2 client & $355.680,30$ & $2 \%$ \\
\cline { 2 - 4 } & 3 client & $13.669,03$ & $2,3 \%$ \\
\cline { 2 - 4 } & Rata-rata & $184.674,66$ & $2,15 \%$ \\
\hline
\end{tabular}

Keterangan kategori:
1) Warna hijau
$=$ Sangat bagus
(nilai indeks 4)
2) Warna orange
$=$ Bagus
$=$ Sedang
(nilai indeks 3)
3) Warna kuning
$=$ Jelek (nilai indeks 2) (nilai indeks 1) 


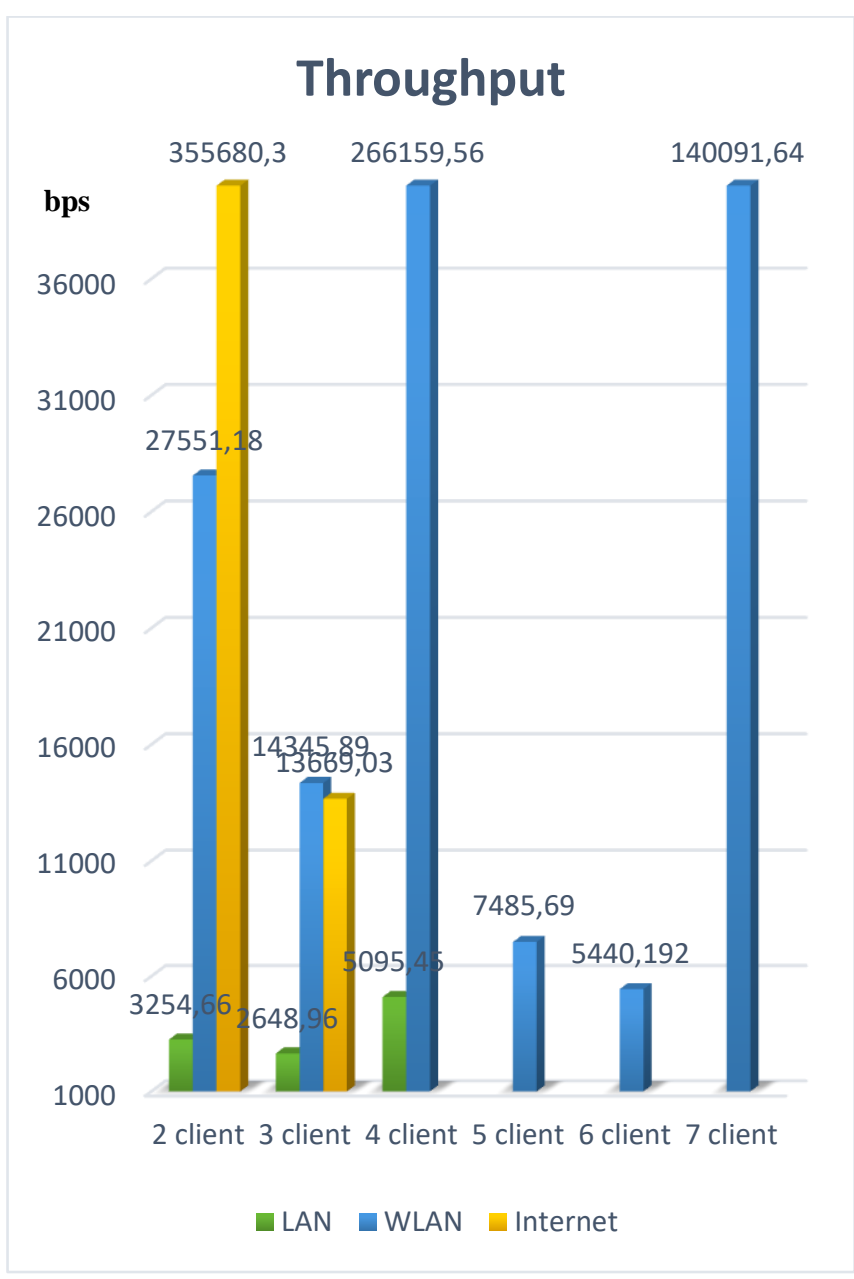

Gambar 16. Unjuk kerja grafik QoS parameter throughput

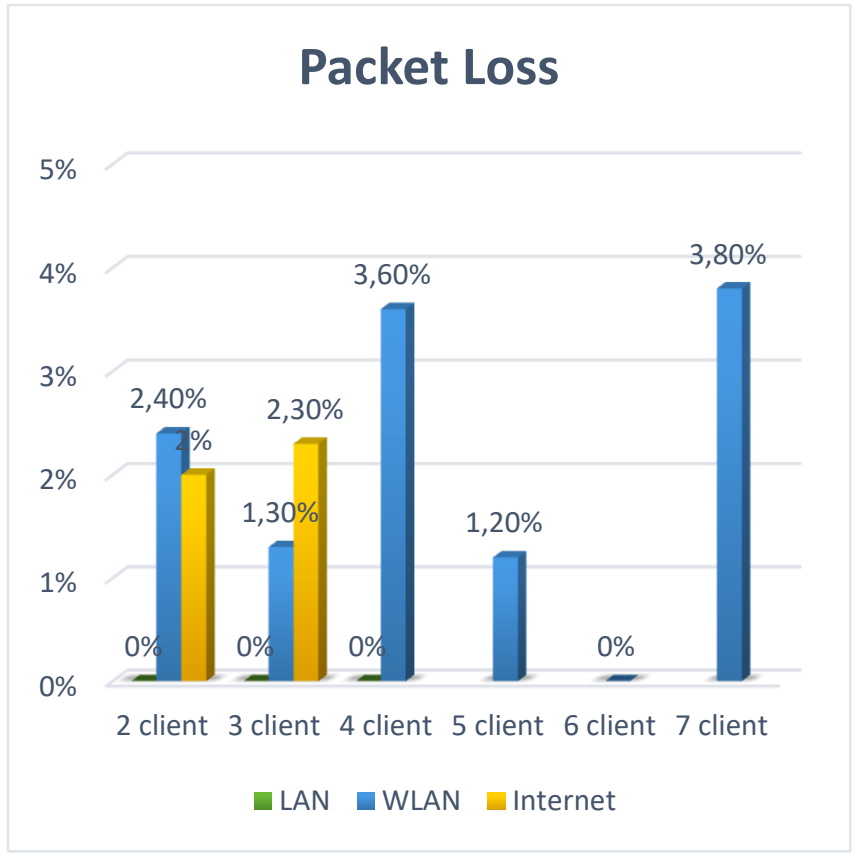

Gambar 17. Unjuk kerja grafik QoS parameter packet loss

\section{Pembahasan}

Berdasarkan percobaan yang telah dilakukan dengan LAN WLAN dan internet dengan VPN dapat diketahui bahwa server video conference menggunakan OpenMeetings berjalan dengan sukses sesuai dengan apa yang diharapkan. Beberapa client dapat melakukan video conference dengan lancar.

Untuk percobaan dengan jaringan LAN, batas maksimum jumlah client yang dapat melakukan video conference adalah 4 client. Hal tersebut karena keterbatasan jumlah port MikroTik yang digunakan. Namun pada dasarnya jumlah client tersebut masih bisa ditambah dengan menambahkan switch atau router yang lain. Dari hasil perhitungan QoS didapatkan hasil rata-rata throughput yaitu 3.666,356 bps. Ini berarti throughput tersebut termasuk dalam kategori sangat bagus dalam standar TIPHON. Untuk packet loss didapatkan nilai sebesar $0 \%$ artinya semua data yang dikirim dapat diterima dengan baik atau dalam kata lain tidak ada paket yang hilang. Maka termasuk dalam kategori bagus.

Percobaan dengan jaringan WLAN menggunakan 7 client, namun bisa lebih dari 7 client tergantung dalam batas maksimal client dalam rooms yang dipilih pada OpenMeetings. Nilai rata-rata throughput yang didapat adalah sebesar 76.845,692 bps dan termasuk dalam kategori sangat bagus dalam standar TIPHON. Rata-rata packet loss yang didapatkan adalah sebesar 3,8\% artinya ada beberapa packet yang hilang dan termasuk dalam kategori bagus.

Percobaan dengan jaringan internet menggunakan teknologi VPN mendapatkan hasil QoS dengan kategori sangat bagus. Nilai rata-rata throughput adalah 184.674,66 bps termasuk dalam kategori sangat bagus dalam standar TIPHON. Rata-rata packet loss adalah sebesar 2,15\% walaupun ada beberapa paket yang hilang, namun hal tersebut masih termasuk dalam kategori yang sangat bagus menurut standar TIPHON.

\section{KESIMPULAN}

Dari percobaan yang telah dilaksanakan, maka dapat disimpulkan bahwa sistem video conference menggunakan OpenMeetings berjalan sesuai dengan yang diharapkan. Hal ini berarti implementasi video conference dengan OpenMeetings telah berhasil. Perhitungan QoS dengan beberapa parameter diantaranya throughput dan packet loss menggunakan jaringan LAN, WLAN dan Internet dengan VPN. Hasil QoS yang didapatkan termasuk dalam sangat baik dalam standar TIPHON.

\section{UCAPAN TERIMA KASIH}

Penulis mengucapkan terima kasih kepada semua pihak yang telah ikut serta membantu dalam terlaksananya penelitian ini. Terutama kepada kedua orang tua yang telah membantu baik dalam hal materil maupun moril. Serta 
kepada kedua dosen pembimbing tugas akhir yang senantiasa memberikan saran dan masukan dalam penelitian ini sehingga penelitian ini dapat terlaksana.

\section{DAFTAR ACUAN}

[1] R. M. Herdiansyah, W. A. P, and D. F. K, "Quality Of Service ( Qos ) Layanan Video Conference Pada Jaringan High Speed Packet Access ( HSPA ) Menggunakan Emulator Graphical Network Simulator ( GNS ) 3," J. Mhs. Tek. Elektro, p. 4, 2014.

[2] D. Pranindito, "Simulasi Dan Analisis QoS Video Conference Melalui Jaringan Interworking IMS - UMTS Menggunakan Opnet," J. Infotel, vol. 9, no. 1, pp. 147-157, 2017, doi: 10.20895/infotel.v9i1.151.

[3] I. Afrianto and E. B. Setiawan, "Kajian virtual private network (vpn) sebagai sistem pengamanan data pada jaringan komputer (studi kasus jaringan komputer unikom)," Maj. Ilm. UNIKOM, vol. 12, no. 1, pp. 43-52, 2015, doi: 10.34010/miu.v12i1.34.

[4] Mexious Media, "FreeDDNS." https://www.hostddns.us/.
[5] C. A. Pamungkas, "Manajemen bandwith menggunakan mikrotik routerboard di politeknik indonusa surakarta," Inf. Politek. Indonusa Surakarta, vol. 1, pp. 3-8, 2016.

[6] F. Ferdianti, L. Ambarwati, M. Chatrine, and K. Paramitha, "Perancangan Sistem Informasi Video Conference Untuk Mendukung Rapat," 2012.

[7] A. Wati, S. Suroso, and S. Sarjana, "Analisis Kualitas Layanan QoS Video Conference pada Jaringan 4G LTE dengan Menggunakan Codec H.264," TELKA - Telekomun. Elektron. Komputasi dan Kontrol, vol. 4, no. 2, pp. 103-113, 2018, doi: 10.15575/telka.v4n2.103-113.

[8] H. Kuswanto, "Implementasi Jaringan Virtual Private Network (VPN) Menggunakan Protokol EoIP," Paradigma, vol. 19 , no. 1, pp. 46-51, 2017.

[9] R. Wulandari, "Analisis Qos (Quality Of Service) Pada Jaringan Internet (Studi Kasus: Upt Loka Uji Teknik Penambangan Jampang Kulon - LIPI)," J. Tek. Inform. dan Sist. Inf., vol. 2, no. 2, pp. 162-172, 2016, doi: 10.28932/jutisi.v2i2.454.

[10] Apache Software Foundation, "Apache OpenMeetings Features and Overview." https://openmeetings.apache.org/. 